\title{
Preoperative serum thyroglobulin concentration as a predictive factor of malignancy in small follicular and Hürthle cell neoplasms of the thyroid gland
}

Rok Petric, Hana Besic and Nikola Besic ${ }^{*}$

\begin{abstract}
Background: Cytologic examination of a fine-needle aspiration biopsy specimen cannot distinguish between benign and malignant follicular or Hürthle cell neoplasms. Serum thyroglobulin (Tg) concentrations are higher in follicular and Hürthle cell carcinomas than in benign follicular or Hürthle cell tumors, but preoperative measurement of $\mathrm{Tg}$ is not recommended for initial evaluation of thyroid nodules. The aim of this study was to find out whether preoperative serum $\mathrm{Tg}$ concentration is a predictive factor of malignant disease in patients with a follicular or Hürthle cell neoplasm with a diameter of $2 \mathrm{~cm}$ or less.

Methods: From 1988 to 2013, a total of 244 patients (214 female, 30 male, age range 9 to 82 years, median age 52 years) had a surgical procedure at our institute because of follicular or Hürthle cell neoplasms with a tumor diameter of $2 \mathrm{~cm}$ or less. In these patients a preoperative concentration of Tg was determined and Tg-autoantibodies were negative. The risk factors for malignancy were identified by a chi-square test and multivariate logistic regression.
\end{abstract}

Results: The histopathologic diagnoses were carcinoma, adenoma, and benign goiter in 62 (25.5\%), 115 (47\%), and 67 (27.5\%) patients, respectively. The median preoperative Tg concentration in benign tumors, papillary carcinomas, follicular carcinomas, and Hürthle cell carcinomas was 41, 87, 72, and $106 \mathrm{ng} / \mathrm{ml}(P=0.05)$, respectively. The predictive factors for carcinoma shown by the chi-square test were: sex, thyroid volume, and preoperative $\mathrm{Tg}$ concentration. The independent predictors of malignancy as shown by multivariate logistic regression were: male sex (odds ratio, 2.57; $P=0.02$ ), and a $\mathrm{Tg}$ concentration of more than $80 \mathrm{ng} / \mathrm{ml}$ (odds ratio, 2.35; $P=0.005$ ).

Conclusion: The independent predictors of malignancy in follicular or Hürthle cell neoplasms are sex and preoperative Tg concentration.

Keywords: follicular carcinoma, Hürthle cell carcinoma, predictive factors, thyroglobulin, thyroid

\section{Background}

Thyroid nodules are a common clinical problem [1], and harbor thyroid cancer in $5 \%$ to $15 \%$ of cases [2]. A thyroid nodule is most accurately evaluated by an ultrasoundguided fine-needle aspiration biopsy (FNAB) [1]. However, in the preoperative diagnosis of follicular and Hürthle cell tumors, FNAB has limited usefulness [3-5]. In follicular and Hürthle cell tumors, malignancy is confirmed by

\footnotetext{
*Correspondence: nbesic@onko-i.si

Department of Surgical Oncology, Institute of Oncology, Zaloska 2, SI-1000 Ljubljana, Slovenia
}

demonstration of transcapsular or vascular invasion, which cannot be seen on cytologic slides [3,6-9]. In follicular or Hürthle cell neoplasms, cytology cannot distinguish a malignant tumor from a benign one $[8,9]$. Confirmation of malignancy is possible only with histological examination of the tumor. Therefore, patients with an FNAB-proven follicular or Hürthle cell neoplasm should be treated surgically. Unfortunately, intraoperative frozen-section analysis is not reliable and does not affect intraoperative decision-making $[10,11]$.

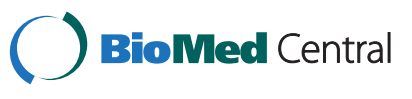


In the case of a follicular or Hürthle cell neoplasm, the American Thyroid Association guidelines recommend a lobectomy or total thyroidectomy [1]. Total thyroidectomy is preferable in patients who have bilateral nodular disease, who have large tumors $(>4 \mathrm{~cm})$, when marked atypia is seen on the biopsy, or who prefer to undergo bilateral thyroidectomy to avoid the possibility of requiring future surgery on the contralateral lobe [1]. A completion of thyroidectomy may be necessary if malignancy is confirmed by histologic examination after a lobectomy [1]. Reliable predictive factors for malignancy are needed, to decrease the number of thyroid reoperations [12-14].

The levels of thyroglobulin $(\mathrm{Tg})$ can be elevated in many thyroid diseases $[1,15]$. So, according to the European and American Thyroid Associations, preoperative Tg measurement is an insensitive and non-specific diagnostic test for thyroid cancer $[1,15]$. In subjects with mild-to-moderate iodine deficiency, the serum Tg concentration correlates with the size of the goiter, the presence of multinodularity and intake of iodine [16]. Furthermore, the thyroid volume, as well as the Tg concentration, is inversely related to iodine intake [16]. However, our previous studies in patients with large follicular or Hürthle cell neoplasms (median size $3 \mathrm{~cm}$ ) showed that measurement of the preoperative serum $\mathrm{Tg}$ concentration may represent a useful preoperative diagnostic test. Namely, the concentration of serum Tg was higher in follicular and Hürthle cell cancers than in benign neoplasms [12-14]. However, the majority of thyroid neoplasms are smaller than $2 \mathrm{~cm}$ [17]. The aim of our retrospective study was to find out if serum $\mathrm{Tg}$ is a predictive factor for malignancy in follicular or Hürthle cell neoplasms with a diameter of $2 \mathrm{~cm}$ or less.

\section{Methods}

\section{Patients}

A chart review of 244 patients (214 female, 30 male, age range 9 to 82 years, median age 52 years) was performed. These patients had a surgical procedure at our institute from 1988 to 2013 because of follicular or Hürthle cell neoplasms with a diameter of $2 \mathrm{~cm}$ or less. In all patients, the preoperative concentration of $\mathrm{Tg}$ was determined and a test for $\mathrm{Tg}$-autoantibodies was negative. The clinical data of these patients are presented in Table 1 . All patients $(N=38)$ with Tg-autoantibodies were excluded from our analysis.

All patients had a follicular or Hürthle cell neoplasm diagnosed by FNAB and cytology. FNABs were ultrasound-guided in the majority of cases. FNABs were performed using a 21-23 gage needle attached to a $10 \mathrm{ml}$ syringe. All cytologic slides were examined by cytopathologists and histologic slides by pathologists, all of them experienced in thyroid pathomorphology. Routine cytologic and final pathology reports were used in this study.
Clinically, the dominant nodule was either solitary or in a multinodular goiter in 160 and 84 cases, respectively (Table 1). The sizes of the thyroid gland and the dominant nodule were determined on the basis of measurements performed during the pathologic examination of the biopsy material. The thyroid volume was calculated by summing the volumes of both lobules. The volume of each lobe was calculated using the formula:

$$
\text { Maximal length } \times \text { Width } \times \text { Depth } \times \pi / 6
$$

as already reported [14].

Our study was reviewed and approved by the Institutional Review Board of the Institute of Oncology, Ljubljana. It was performed in accordance with the ethical standards laid down in an appropriate version of the 1964 Declaration of Helsinki. Our study was conducted with the understanding and consent of the subjects. All our patients were asked during first admission to our institute or a follow-up visit to give consent for the study of their charts and biopsy material for scientific purposes. Since the Institutional Review Board of the Institute of Oncology Ljubljana approved this specific study, our patients were not asked to give written consent on this specific study.

\section{Laboratory}

From 1988 to 2001 and from 2007 to 2008, serum Tg measurements were carried out using the commercially available Dyno-test Tg/Tg-S RIA kit (Henning/Brahms, Germany), which includes the determination of Recovery$\mathrm{Tg}$. Normal values of Recovery-Tg were considered to rule out the possibility of disturbing influence exerted by Tg-autoantibodies or other non-specific serum proteins. From 2001 to 2007, serum Tg and Tg-autoantibody concentrations were determined by the commercially available LIAISON Tg and LIAISON Anti-Tg kits, respectively, with the LIAISON analyzer (all from Byk-Sangtec Diagnostica/DiaSorin, Germany/Italy). From 2008 onwards, serum $\mathrm{Tg}$ and $\mathrm{Tg}$-autoantibody concentrations were determined by the commercially available $\mathrm{Tg} / \mathrm{Tg}$-II Cobas and Anti-Tg kits, respectively, with a Modular analyzer (all from Roche, Germany).

Owing to the presence of Tg-autoantibodies, 38 patients were excluded from the study.

\section{Statistical analysis}

The predictive factors for malignancy were identified by a chi-square test. Only the status of the dominant nodule was used for the analysis of factors correlating with the presence of malignancy. A receiver operating characteristic (ROC) analysis was performed to define the cutoff for Tg levels. A cut-off for Tg values was chosen at $80 \mathrm{ng} / \mathrm{ml}$ on the basis of a ROC curve. The sensitivity, 
Table 1 Clinical data of $\mathbf{2 4 4}$ patients with follicular and Hürthle cell neoplasms with diameter $\mathbf{2}$ cm or less

\begin{tabular}{|c|c|c|c|c|}
\hline Characteristic & Subgroup & Benign $N=182(\%)$ & Carcinoma $N=62(\%)$ & Chi-square test $P$ value \\
\hline \multirow[t]{4}{*}{ Age (years) } & 45 or younger & $57(24 \%)$ & $23(9 \%)$ & 0.44 \\
\hline & Older than 45 & $125(51 \%)$ & $39(16 \%)$ & \\
\hline & 65 or younger & $163(67 \%)$ & $54(22 \%)$ & 0.64 \\
\hline & Older than 65 & $19(8 \%)$ & $8(3 \%)$ & \\
\hline \multirow[t]{2}{*}{ Sex } & Male & $17(7 \%)$ & $13(5 \%)$ & 0.024 \\
\hline & Female & $165(68 \%)$ & 49 (20\%) & \\
\hline \multirow[t]{2}{*}{ Dominant tumor } & In multinodular goiter & $61(25 \%)$ & $23(9 \%)$ & 0.64 \\
\hline & Solitary & $121(50 \%)$ & $39(16 \%)$ & \\
\hline \multirow[t]{2}{*}{ Tumor diameter $(\mathrm{cm})$} & 1 or less & $42(17 \%)$ & $13(5 \%)$ & 0.86 \\
\hline & More than 1 & $140(58 \%)$ & 49 (20\%) & \\
\hline \multirow[t]{4}{*}{ Thyroid volume (ml) } & 29 or less & $149(61 \%)$ & 47 (19\%) & 0.36 \\
\hline & 30 or more & $33(14 \%)$ & $15(6 \%)$ & \\
\hline & 49 or less & $169(70 \%)$ & $52(21 \%)$ & 0.045 \\
\hline & 50 or more & $13(5 \%)$ & $10(4 \%)$ & \\
\hline \multirow[t]{4}{*}{ Serum $\mathrm{Tg}$ concentration $(\mathrm{ng} / \mathrm{ml})$} & 79 or less & 120 (49\%) & 28 (11\%) & 0.004 \\
\hline & 80 or more & $62(26 \%)$ & $34(14 \%)$ & \\
\hline & 299 or less & $168(69 \%)$ & $51(21 \%)$ & 0.031 \\
\hline & 300 or more & $14(6 \%)$ & $11(4 \%)$ & \\
\hline
\end{tabular}

specificity, and positive and negative predictive values of elevated Tg concentrations for the presence of carcinoma were calculated. The following factors were included in the univariate and multivariate statistical analyses: the sex of the patients, volume of the thyroid gland, and Tg concentration. The variables that showed statistical correlation $(P<0.05)$ by logistic regression analysis were considered as independent predictive factors for malignancy. SPSS 16.0 for Windows was used for statistical analysis.

\section{Results}

The median age of the patients, tumor size, volume of the thyroid gland, median and mean concentration of preoperative Tg were 52 years (range, 9 to 82 ), $1.5 \mathrm{~cm}$ (range, 0.4 to 2), $20 \mathrm{ml}$ (range, 5 to 162 ), $50 \mathrm{ng} / \mathrm{ml}$ (range, 1 to 3,424), and 125 (range 1 to 3,424) ng/ml, respectively. The histopathologic diagnoses were carcinoma, adenoma, and benign goiter in 62 (25.5\%), 115 (47\%), and 67 (27.5\%) patients, respectively.

The median age of patients with carcinoma was 52.5 years, while the median age of those with a benign disease was 52 years. The median size of the tumor was $1.55 \mathrm{~cm}$ in patients with carcinoma and $1.5 \mathrm{~cm}$ in those with a benign disease. Tumor diameter did not correlate with malignancy rate $(P=0.225)$. These data are presented in Table 2 and Figures 1 and 2.

The median preoperative $\mathrm{Tg}$ concentrations in patients with and without carcinoma were 86 and $41 \mathrm{ng} / \mathrm{ml}$, respectively. The mean preoperative $\mathrm{Tg}$ concentrations in patients with and without carcinoma were 215 and $95 \mathrm{ng} / \mathrm{ml}$, respectively. The median preoperative $\mathrm{Tg}$ concentrations in benign tumors, papillary carcinomas, follicular carcinomas, and Hürthle cell carcinomas were 41, 87, 72, and $106 \mathrm{ng} / \mathrm{ml}(P<0.05)$, respectively. The mean preoperative $\mathrm{Tg}$ concentrations in benign tumors, papillary carcinomas, follicular carcinomas, and Hürthle cell carcinomas were 95, 147, 433, and $269 \mathrm{ng} / \mathrm{ml}(P<0.001)$, respectively. Tg concentrations in different types of carcinoma in the dominant nodule are listed in Table 3. As shown by logistic regression analysis, concentration of $\mathrm{Tg}$ (cut-off point of $80 \mathrm{ng} / \mathrm{ml}$ ) was an independent predictive factor. The ROC analysis showed that the area under the curve was $0.613(P=0.008)$. The sensitivity and specificity of the test, positive predictive value, and negative predictive value (cut-off $=\mathrm{Tg}$ concentration of $80 \mathrm{ng} / \mathrm{ml}$ ) for the presence of carcinomas in small follicular and Hürthle cell neoplasms of the thyroid gland were $54.8 \%, 31.1 \%, 35.4 \%$, and $81 \%$, respectively.

Predictive factors for malignancy in follicular or Hürthle cell neoplasms as shown by the chi-square test were: sex, volume of the thyroid gland, and Tg concentration (Table 1). The independent predictors of malignancy as shown by multivariate logistic regression were: sex and preoperative $\mathrm{Tg}$ concentration (Table 4). Male patients had a higher risk of carcinoma than female patients (odds ratio, 2.57). In male patients, the malignancy rate was $43 \%$, while in female patients, it was $23 \%$. Patients with a preoperative $\mathrm{Tg}$ concentration of $80 \mathrm{ng} / \mathrm{ml}$ or higher had a higher risk of malignancy than those with a 
Table 2 Tumor size, presence of carcinoma, and Tg concentration

\begin{tabular}{lccc}
\hline Tumor size $(\mathbf{c m})$ & Number of patients & $\begin{array}{c}\text { Benign tumor median (range) Tg } \\
\text { concentration } \mathbf{n g} / \mathbf{m l}\end{array}$ & $\begin{array}{c}\text { Carcinoma median (range) Tg } \\
\text { concentration } \mathbf{~ n g} / \mathbf{m l}\end{array}$ \\
\hline $\mathbf{0 . 0 1}$ to $\mathbf{0 . 5}$ & 9 & $12(11$ to 27$)$ & $60(1$ to 974$)$ \\
$\mathbf{0 . 5 1}$ to $\mathbf{1}$ & 46 & $18(1$ to 839$)$ & $32(2$ to 441$)$ \\
$\mathbf{1 . 0 1}$ to $\mathbf{1 . 5}$ & 83 & $41(2$ to 1,026$)$ & $119(3$ to 3,424$)$ \\
$\mathbf{1 . 5 1}$ to $\mathbf{2}$ & 106 & $62(3$ to 860$)$ & $90(1$ to 1,757$)$ \\
\hline
\end{tabular}

lower concentration (odds ratio, 2.35). In patients with a $\mathrm{Tg}$ concentration of $80 \mathrm{ng} / \mathrm{ml}$ or more, the malignancy rate was $35 \%$, while in those with a smaller Tg concentration, it was $19 \%$.

Incidental carcinoma in a non-dominant tumor was detected in 13 patients. It was detected in patients with a benign disease and carcinoma of the dominant nodule in $9(5 \%)$ and $4(6 \%)$ of cases, respectively. In patients with carcinoma in the dominant nodule, final pathology additionally revealed a benign goiter, benign adenoma, and thyroiditis in 21, 10, and 27 cases, respectively.

\section{Discussion}

The following predictive factors of malignancy have been reported in the literature [5,13,14,17-41]: the patient's age $[18,19,24,25,30-33]$ and sex $[5,26]$, the tumor size [5,18,20-22,24-26,31-36,42], a solitary nodule [24,26,27], tumor fixation [25], a lesion that feels hard on palpation [27], $\mathrm{Tg}$ concentration [13,14,18], ultrasound characteristics [17,27-29,41], cytologic characteristic [21], and gene expression diagnostic markers [37-40]. Ultrasound

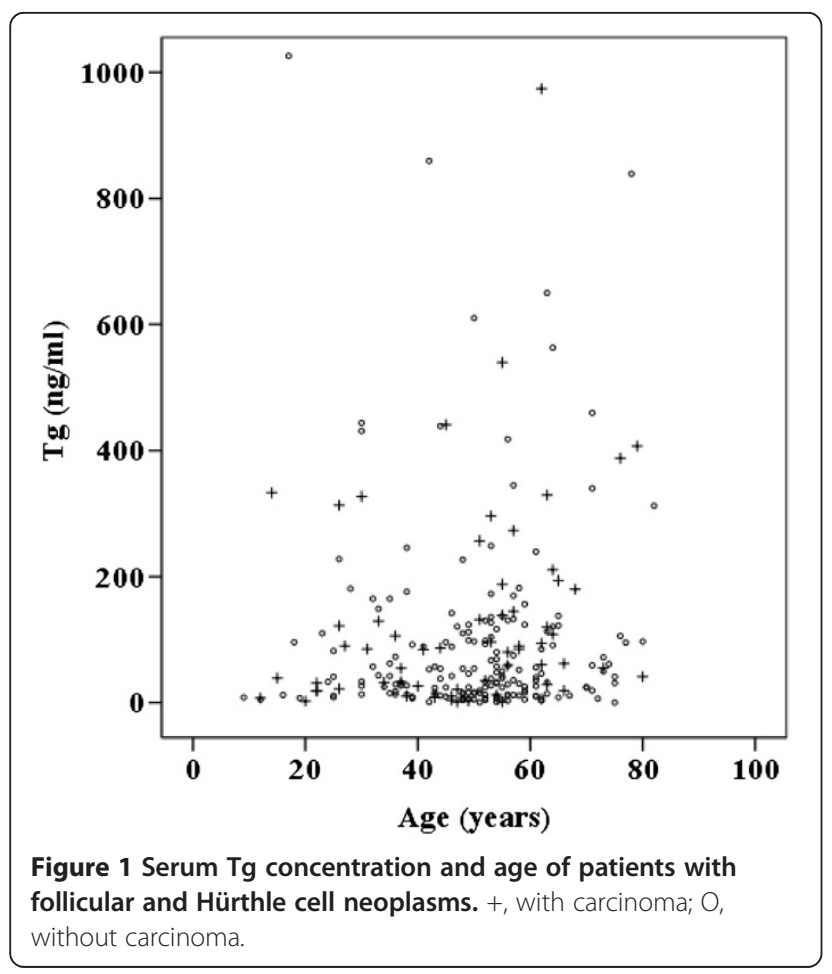

characteristics predictive of malignancy are: the presence of internal blood flow (as detected by Doppler ultrasonography), the presence of hypervascularity, a solid echo structure, a hypoechoic lesion, or microcalcifications [17,27-29,41]. New cytologic characteristics were also reported as factors predictive of malignancy: transgressing vessel [21] and nuclear grooves [21]. New gene expression diagnostic markers of malignancy are: miR100, miR-125b, miR-138, miR-768-3p, miRNA-885-5p, and a combination of genes PVALB and C1orf24 [37-40]. However, a vast majority of reports on predictive factors in follicular or Hürthle cell neoplasms included only a small number of patients; thus, the authors of these studies could perform only a univariate statistical analysis. To our knowledge, so far only eight publications $[13,14,17,18,21,25,26,41]$ have reported the results of multivariate logistic regression analysis of predictive factors in patients with follicular or Hürthle cell neoplasms.

Carcangiu et al. [30], Lopez-Penabad et al. [31], Taneri et al. [32], and Zhang et al. [33] stated that patients with carcinoma were older than those with a benign disease.

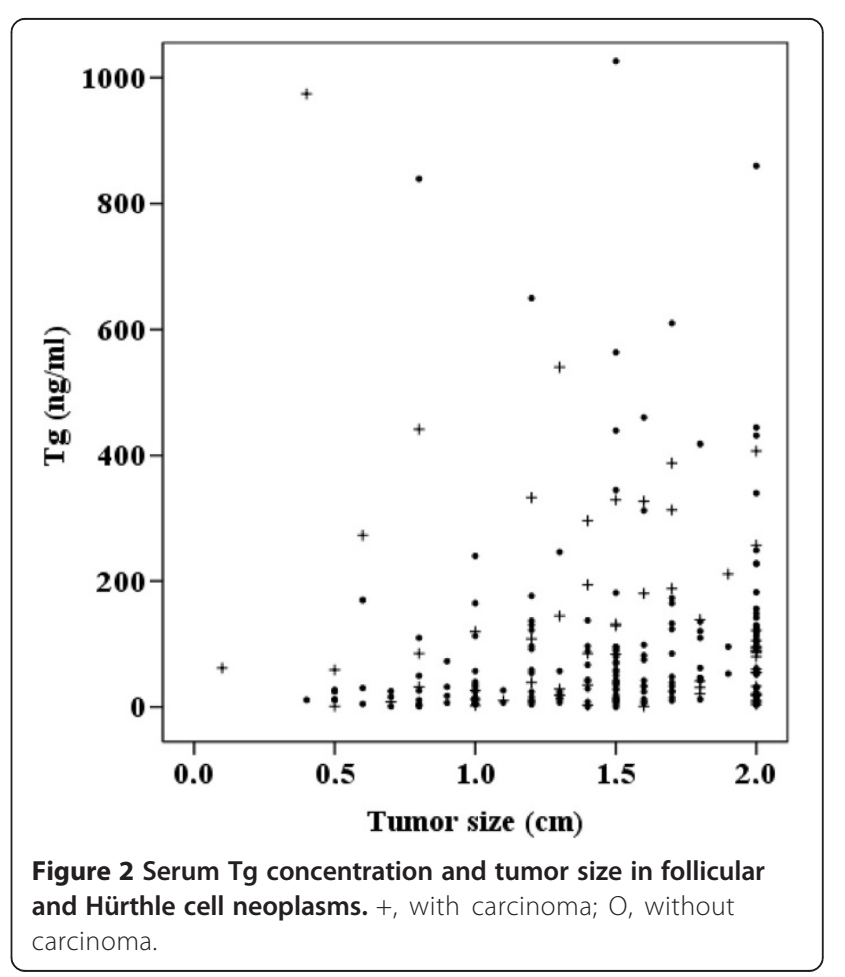


Table 3 Histology of follicular and Hürthle cell neoplasms and $\mathrm{Tg}$ concentration

\begin{tabular}{lccc}
\hline Histology & $\begin{array}{c}\text { Number of } \\
\text { patients }\end{array}$ & $\begin{array}{c}\text { Tg concentration } \\
\text { ng/ml (range) }\end{array}$ & $\begin{array}{c}\text { Tg concentration } \\
\text { ng/ml (median) }\end{array}$ \\
\hline Carcinoma & $\mathbf{6 2}$ & $\mathbf{1}$ to $\mathbf{3 , 4 2 4}$ & $\mathbf{8 6}$ \\
Follicular & 10 & 2 to 3,424 & 72 \\
Hürthle cell & 11 & 1 to 1,757 & 106 \\
$\begin{array}{l}\text { Papillary, classic } \\
\text { type }\end{array}$ & 9 & 1 to 974 & 85 \\
$\begin{array}{l}\text { Papillary, } \\
\text { follicular type }\end{array}$ & 31 & 1 to 540 & 90 \\
$\begin{array}{l}\text { Papillary, } \\
\text { Hürthle cell }\end{array}$ & 1 & 4 & 4 \\
Benign tumor & $\mathbf{1 8 2}$ & $\mathbf{1}$ to $\mathbf{1 , 2 0 3}$ & $\mathbf{4 1}$ \\
Adenoma & 115 & 1 to 1,026 & 32 \\
Benign goiter & 67 & 1 to 839 & 54 \\
\hline
\end{tabular}

Benign tumors versus papillary carcinomas and versus follicular or Hürthle cell carcinomas $(P<0.001)$.

However, the median age of our patients with carcinoma was not statistically different from the median age of those with a benign disease ( 52.5 years versus 52 years). Our findings are in agreement with the majority of reports from the literature.

Mihai et al. [5] and Tuttle et al. [26] found that the risk of carcinoma was higher in men than in women. This is in agreement with the findings of our study. In our study, men had a higher risk of carcinoma than women (an odds ratio of 2.57). The malignancy rate in men in our study was $43 \%$, while in women it was $23 \%$.

Many authors reported that the size of follicular neoplasms increases the risk of malignancy $[5,18,20-22$, 24-26,28,31-36,42]. Tuttle et al. [26] reported that the risk of carcinoma in a tumor larger than $4 \mathrm{~cm}$ was $40 \%$, while in smaller tumors it was only $13 \%$. In our patients with a tumor diameter of $2 \mathrm{~cm}$ or less, the risk of carcinoma was $25.5 \%$. In Hürthle cell neoplasms, Taneri et al. [32] found that there was no malignancy among the tumors less than $1 \mathrm{~cm}$ in diameter. But our findings are quite the opposite. In our patients, the malignancy rate did not differ in patients with a tumor diameter of $1 \mathrm{~cm}$ or less versus bigger tumors (Table 1 ).

Table 4 Independent risk factors for malignancy in follicular or Hürthle cell neoplasms

\begin{tabular}{llll}
\hline Factor & Subgroup & Odds ratio & $\begin{array}{l}\mathbf{9 5 \%} \text { confidence } \\
\text { interval }\end{array}$ \\
\hline Sex & Female & 1 & 1.15 to 5.75 \\
& Male & 2.57 & \\
Serum Tg & 79 or less & 1 & 1.30 to 4.25 \\
concentration $(\mathbf{n g} / \mathbf{m l})$ & 80 or more & 2.35 & \\
\hline
\end{tabular}

The likelihood of malignancy as calculated by logistic regression (model summary: chi-square: $13.747 ; 2$ degrees of freedom; $P=0.002 ;-2$ log likelihood of 263.32).
Hocevar and Auersperg [12] found that preoperative $\mathrm{Tg}$ concentration was higher in patients with follicular and Hürthle cell carcinoma than in patients with benign tumors. In Hürthle cell neoplasms, Sugino et al. [42] reported that in patients with carcinoma and benign disease the median $\mathrm{Tg}$ concentration was $1,782 \mathrm{ng} / \mathrm{ml}$ and $573 \mathrm{ng} / \mathrm{ml}$, respectively. Strazisar et al. [14] and Petric et al. [13] reported that there was a statistical difference in preoperative Tg concentrations of benign tumors, papillary carcinomas, follicular carcinomas, and Hürthle cell carcinomas. Moreover, the results of the present study show that the mean preoperative $\mathrm{Tg}$ concentration was significantly different $(P<0.05)$ in benign tumors, papillary carcinomas, follicular carcinomas, and Hürthle cell carcinomas. The median preoperative $\mathrm{Tg}$ concentrations in benign tumors, papillary carcinomas, follicular carcinomas, and Hürthle cell carcinomas were 41, 87, 72, and $106 \mathrm{ng} / \mathrm{ml}$, respectively. However, in contrast to our findings, Suh et al. [23] found, in only 39 patients with follicular or Hürthle cell neoplasms, that $\mathrm{Tg}$ was not an independent risk factor [23]. The median preoperative levels of the Tg serum were, in patients with malignant and in patients with benign tumors, $135 \mathrm{ng} / \mathrm{ml}$ and $116 \mathrm{ng} / \mathrm{ml}$, respectively [23]. Their patients had bigger tumors than did the patients from our present study. Their patients' $\mathrm{Tg}$ concentrations were larger than ours, probably because the median tumor size of their patients was bigger than in our study. The median diameter of their malignant and benign tumors was $2.8 \mathrm{~cm}$ and $2.4 \mathrm{~cm}$, respectively.

The aim of this study was to find out whether $\mathrm{Tg}$ is a predictive factor of malignancy in 244 small $(2 \mathrm{~cm}$ or less) follicular or Hürthle cell neoplasms. In our study, the concentration of $\mathrm{Tg}$ was an independent predictive factor of malignancy. Patients with a preoperative $\mathrm{Tg}$ concentration of at least $80 \mathrm{ng} / \mathrm{ml}$ had a higher risk of malignancy than those with a lower concentration (an odds ratio of 2.35). In patients with a $\mathrm{Tg}$ concentration of $80 \mathrm{ng} / \mathrm{ml}$ or more, the malignancy rate was $35 \%$, while in those with a smaller $\mathrm{Tg}$ concentration, it was only $19 \%$. We believe that determination of $\mathrm{Tg}$ concentration may be one of the factors that are useful in follicular or Hürthle cell neoplasms before determining the extent of the thyroid surgical procedure.

\section{Conclusions}

The malignancy rate in this study of 244 patients with follicular or Hürthle cell neoplasms with a tumor diameter of $2 \mathrm{~cm}$ or less was $25.5 \%$. The independent predictors of malignancy in follicular or Hürthle cell neoplasms are: sex and preoperative $\mathrm{Tg}$ concentration.

\section{Abbreviations}

FNAB: fine-needle aspiration biopsy; ROC: receiver operating characteristic; Tg: thyroglobulin. 


\section{Competing interests}

The authors declare that there are no competing interests that could be perceived as prejudicing the impartiality of this paper.

\section{Authors' contributions}

RP participated in the design of the study, collected data, performed the statistical analysis, and drafted the manuscript. NB participated in the design of the study and drafted the manuscript. HB collected data. All authors read and approved the final manuscript.

\section{Acknowledgement}

This paper is a part of Research Study No. P3-0289 supported by the Ministry of Higher Education, Science, and Technology of the Republic of Slovenia.

Received: 10 July 2014 Accepted: 2 September 2014

Published: 12 September 2014

\section{References}

1. American Thyroid Association (ATA) Guidelines Taskforce on Thyroid Nodules and Differentiated Thyroid Cancer, Cooper DS, Doherty GM Haugen BR, Kloos RT, Lee SL, Mandel SJ, Mazzaferri EL, Mclver B, Pacini F, Schlumberger M, Sherman SI, Steward DL, Tuttle RM: Revised American Thyroid Association management guidelines for patients with thyroid nodules and differentiated thyroid cancer. Thyroid 2009, 19:1167-1214.

2. Hegedus L: Clinical practice. The thyroid nodule. N Engl J Med 2004, 351:1764-1771.

3. Baloch ZW, LiVolsi VA: Our approach to follicular-patterned lesions of the thyroid. J Clin Pathol 2007, 60:244-250.

4. DeMay RM: Follicular lesions of the thyroid. Am J Clin Pathol 2000, 114:681-683.

5. Mihai R, Parker AJ, Roskell D, Sadler GP: One in four patients with follicular thyroid cytology (THY3) has a thyroid carcinoma. Thyroid 2009, 19:33-37.

6. Hedinger C, Wiliams ED, Sobin LH: The WHO histological classification of thyroid tumors: a commentary on the second edition. Cancer 1989, 63:908-911.

7. Rosai J: Tumors of the thyroid gland. In Atlas of Tumor Pathology. Edited by Rosai J, Carcangiu ML, Delellis RA. Washington: Armed Forces Institute of Pathology; 1992:31-50

8. Baloch ZW, Fleisher S, LiVolsi VA, Gupta PK: Diagnosis of 'follicular neoplasm': a gray zone in thyroid fine-needle aspiration cytology. Diagn Cytopathol 2002, 26:41-44.

9. Baloch ZW, LiVolsi VA: Fine-needle aspiration of the thyroid: today and tomorrow. Best Pract Res Clin Endocrinol Metab 2008, 22:929-939.

10. Lumachi F, Borsato S, Tregnaghi A, Marino F, Polistina F, Basso SM, Koussis $H$, Basso U, Fassina A: FNA cytology and frozen section examination in patients with follicular lesions of the thyroid gland. Anticancer Res 2009, 29:5255-5257.

11. Udelsman R, Westra WH, Donovan PI, Sohn TA, Cameron JL: Randomized prospective evaluation of frozen-section analysis for follicular lesions of the thyroid. Ann Surg 2001, 233:716-722.

12. Hocevar M, Auersperg M: Role of serum thyroglobulin in the preoperative evaluation of follicular thyroid tumors. Eur J Surg Oncol 1998, 24:553-557.

13. Petric R, Perhavec A, Gazic B, Besic N: Preoperative serum thyroglobulin concentration is an independent predictive factor of malignancy in follicular neoplasms of the thyroid gland. J Surg Oncol 2012, 105:351-356.

14. Strazisar B, Petric R, Sesek M, Zgajnar J, Hocevar M, Besic N: Predictive factors of carcinoma in 279 patients with Hürthle cell neoplasm of the thyroid gland. J Surg Oncol 2010, 101:582-586.

15. Pacini F, Schlumberger $M$, Dralle $H$, Elisei $R$, Smit JW, Wiersinga W, European Thyroid Cancer Taskforce: European consensus for the management of patients with differentiated thyroid carcinoma of the follicular epithelium. Eur J Endocrinol 2006, 154:787-803.

16. Rasmussen LB, Ovesen L, Bülow I, Jørgensen T, Knudsen N, Laurberg P, Perrild $\mathrm{H}$ : Relations between various measures of iodine intake and thyroid volume, thyroid nodularity, and serum thyroglobulin. Am J Clin Nutr 2002, 76:1069-1076

17. Ho AS, Sarti EE, Jain KS, Wang H, Nixon IJ, Shaha AR, Shah JP, Kraus DH, Ghossein R, Fish SA, Wong RJ, Lin O, Morris LG: Malignancy rate in thyroid nodules classified as Bethesda Category III (AUS/FLUS). Thyroid 2013, 24:832-839.
18. Besic N, Sesek M, Peric B, Zgajnar J, Hocevar M: Predictive factors of carcinoma in 327 patients with follicular neoplasm of the thyroid. Med Sci Monit 2008, 14:CR459-CR467.

19. Tyler DS, Winchester DJ, Caraway NP, Hickey RC, Evans DB: Indeterminate fine-needle aspiration biopsy of the thyroid: identification of subgroups at high risk for invasive carcinoma. Surgery 1994, 116:1054-1060.

20. Heikkilä A, Siironen P, Hagström J, Heiskanen I, Sankila R, Louhimo J, Haglund C, Arola J: Follicular thyroid neoplasm: clinicopathologic features suggesting malignancy. APMIS 2010, 118:846-854.

21. Lubitz CC, Faquin WC, Yang J, Mekel M, Gaz RD, Parangi S, Randolph GW, Hodin RA, Stephen AE: Clinical and cytological features predictive of malignancy in thyroid follicular neoplasms. Thyroid 2010, 20:25-31.

22. Raparia K, Min SK, Mody DR, Anton R, Amrikachi M: Clinical outcomes for 'suspicious' category in thyroid fine-needle aspiration biopsy: patient's sex and nodule size are possible predictors of malignancy. Arch Pathol Lab Med 2009, 133:787-790.

23. Suh I, Vriens MR, Guerrero MA, Griffin A, Shen WT, Duh QY, Clark OH, Kebebew E: Serum thyroglobulin is a poor diagnostic biomarker of malignancy in follicular and Hürthle-cell neoplasms of the thyroid. Am J Surg 2010, 200:41-46.

24. Paramo JC, Mesko T: Age, tumor size, and in-office ultrasonography are predictive parameters of malignancy in follicular neoplasms of the thyroid. Endocr Pract 2008, 14:447-451.

25. Schlinkert RT, van Heerden JA, Goellner JR, Gharib H, Smith SL, Rosales RF, Weaver AL: Factors that predict malignant thyroid lesions when fine-needle aspiration is 'suspicious for follicular neoplasm'. Mayo Clin Proc 1997, 72:913-916.

26. Tuttle RM, Lemar $\mathrm{H}$, Burch HB: Clinical features associated with an increased risk of thyroid malignancy in patients with follicular neoplasia by fine-needle aspiration. Thyroid 1998, 8:377-383.

27. Raber W, Kaserer K, Niederle B, Vierhapper H: Risk factors for malignancy of thyroid nodules initially identified as follicular neoplasia by fine-needle aspiration: results of a prospective study of one hundred twenty patients. Thyroid 2000, 10:709-712.

28. Gulcelik NE, Gulcelik MA, Kuru B: Risk of malignancy in patients with follicular neoplasm: predictive value of clinical and ultrasonographic features. Arch Otolaryngol Head Neck Surg 2008, 134:1312-1315.

29. Choi YJ, Yun JS, Kim DH: Clinical and ultrasound features of cytology diagnosed follicular neoplasm. Endocr J 2009, 56:383-389.

30. Carcangiu ML, Bianchi S, Savino D, Voynick IM, Rosai J: Follicular Hürthle cell tumors of the thyroid gland. Cancer 1991, 68:1944-1953.

31. Lopez-Penabad L, Chiu AC, Hoff AO, Schultz P, Gaztambide S, Ordoñez NG, Sherman SI: Prognostic factors in patients with Hürthle cell neoplasms of the thyroid. Cancer 2003, 97:1186-1194

32. Taneri F, Tekin E, Salman B, Anadol AZ, Ersoy E, Poyraz A, Onuk E: Hürthle cell neoplasms of the thyroid: predicting malignant potential. Endocr Regul 2000, 34:19-21.

33. Zhang YW, Greenblatta DY, Repplingera D, Bargren A, Adler JT, Sippel RS, Chen $\mathrm{H}$ : Factors that predict malignancy in Hürthle cell neoplasms of the thyroid. J Surg Res 2008, 144:371-2.

34. Chen H, Nicol TL, Zeiger MA, Dooley WC, Ladenson PW, Cooper DS, Ringel M, Parkerson S, Allo M, Udelsman R: Hürthle cell neoplasms of the thyroid: are these factors predictive of malignancy? Ann Surgery 1998, 227:542-546.

35. Pisanu A, Sias L, Uccheddu A: Factors predicting malignancy of Hürthle cell tumors of the thyroid: influence on surgical treatment. World J Surg 2004, 28:761-765.

36. Sippel RS, Elaraj DM, Khanafshar E, Zarnegar R, Kebebew E, Duh QY, Clark $\mathrm{OH}$ : Tumor size predicts malignant potential in Hürthle cell neoplasms of the thyroid. World J Surg 2008, 32:702-707.

37. Freitas BC, Cerutti J: Genetic markers differentiating follicular thyroid carcinoma from benign lesions. Moll Cell Endocrinol 2010, 321:77-85.

38. Cerutti JM, Oler G, Delcelo R, Gerardt R, Michaluart P Jr, de Souza SJ, Galante PA, Huang P, Riggins GJ: PVALB, a new Hürthle adenoma diagnostic marker identified through gene expression. J Clin Endocrinol Metab 2011, 96:E151-E160.

39. Vriens MR, Weng J, Suh I, Huynh N, Guerrero MA, Shen WT, Duh QY, Clark $\mathrm{OH}$, Kebebew E: MicroRNA expression profiling is a potential diagnostic tool for thyroid cancer. Cancer 2012, 118:3426-3432. 
40. Dettmer M, Vogetseder A, Durso MB, Moch H, Komminoth P, Perren A, Nikiforov YE, Nikiforova MN: MicroRNA expression array identifies novel diagnostic markers for conventional and oncocytic follicular thyroid carcinomas. J Clin Endocrinol Metab 2013, 98:E1-E7.

41. Cuhaci N, Arpaci D, Ucler R, Yazgan AK, Kiyak G, Yalçin S, Ersoy PE, Güler G, Ersoy R, Cakir B: Malignancy rate of thyroid nodules defined as follicular lesion of undetermined significance and atypia of undetermined significance in thyroid cytopathology and its relation with ultrasonographic features. Endocr Pathol 2014. doi:10.1007/s12022-014-9298-7.

42. Sugino K, Ito K, Mimura T, Kameyama K, Iwasaki H, Ito K: Hürthle cell tumor of the thyroid: analysis of 188 cases. World J Surg 2001, 25:1160-1163.

doi:10.1186/1477-7819-12-282

Cite this article as: Petric et al:: Preoperative serum thyroglobulin concentration as a predictive factor of malignancy in small follicular and Hürthle cell neoplasms of the thyroid gland. World Journal of Surgical Oncology 2014 12:282.

\section{Submit your next manuscript to BioMed Central and take full advantage of:}

- Convenient online submission

- Thorough peer review

- No space constraints or color figure charges

- Immediate publication on acceptance

- Inclusion in PubMed, CAS, Scopus and Google Scholar

- Research which is freely available for redistribution 